\title{
ДЕЯКІ ОСОБЛИВОСТІ ЗДІЙСНЕННЯ ПЕРЕВІРКИ ДОТРИМАННЯ ВИМОГ ДОЗВІЛЬНОЇ СИСТЕМИ ГРОМАДЯНАМИ ЯК ОДИН ІЗ ВИДІВ ПРЕВЕНТИВНИХ ПОЛІЦЕЙСЬКИХ ЗАХОДІВ
}

Ташматов В. А., Прядко В. М.

\begin{abstract}
У цій статmі будуть розглянуті особливості перевірки поліцейськими дотримання вимог дозвільної системи громадянами - власниками зброї. Громадяни України для здійснення необхідної оборони мають право на придбання вогнепальної зброї, пневматичної зброї і холодної зброї, газових пістолетів і револьверів та патронів до них, заряджених речовинами сльозоточивої та дратівної діі, пристроїв вітчизняного виробничтва для відстрілу патронів, споряджених гумовими чи аналогічними за своїми властивостями метальними снарядами несмертельної дії та патронів до них, основних частин зброї, бойових припасів до зброї.

Ключові слова: поліція, дозвільна система, вогнепальна зброя, поліцейські заходи.
\end{abstract}

В данной статье будут рассмотрены особенности проверки полицейскими соблюдения требований разрешительной системы гражданами - владельцами оружия. Граждане Украины для осуществления необходимой обороны имеют право на приобретение огнестрельного оружия, пневматического оружия и холодного оружия, газовых пистолетов и револьверов и патронов к ним, заряженных веществами слезоточивого и раздражающего действия, устройств отечественного производства для отстрела патронов, снаряженных резиновыми или аналогичными по своим свойствам метательными снарядами несмертельного действия и патронов к ним, основных частей оружия, боеприпасов к оружию.

Ключевые слова: полиция, разрешительная система, огнестрельное оружие, полицейские мероприятия.

The Constitution of Ukraine defines the right of every citizen to protect their lives and the health, life or health of others from unlawful encroachments. Criminal law defines such actions as necessary defense. Necessary defense shall be actions taken to protect the rights and interests of the protected person or other person, as well as the public and state interests from a publicly dangerous encroachment by causing harm to the harming person necessary and sufficient in the given circumstances, immediate deterrence or cessation of the encroachment, if the limits of the necessary defense were not exceeded. Everyone has the right to the necessary defense, regardless of whether he or she is able to avoid a dangerous social attack or to seek the assistance of other persons or authorities. Exceeding the limits of the necessary defense is the intentional infliction of grievous harm on the person who violates, which clearly does not correspond to the danger of the attack or the protection situation. It does not exceed the limits of necessary defense and does not result in criminal liability for the use of weapons or any other means or objects to protect against an attack by an armed person or an attack by a group of persons, as well as to prevent unlawful violent invasion of housing or other premises, regardless of the severity of the damage, that is being caused to the infringer. Citizens of Ukraine for the necessary defense have the right to purchase firearms, airguns and melee weapons,

Ташматов В. А., Прядко В. М., 2019 gas pistols and revolvers and cartridges thereto, charged with tear and irritant substances, devices of domestic production for shooting cartridges, and other equipment non-lethal projectiles, and ammunition to them, major weapons, ammunition. The main tasks of the police authorities in the field of the permit system are to prevent the violation of the order of manufacture, purchase, storage, accounting, protection, transportation and use. The police in the area of the permit system shall monitor the observance of the special rules and procedures for the storage and use of weapons, special personal protective equipment and active defense, ammunition, explosives and materials, other objects, materials and substances covered by the permit system by natural and legal persons. vities.

Key words: police, licensing system, firearms, police acti-

Актуальність дослідження. Порушені в статті питання пов'язані з великою кількістю різноманітної зброї (вогнепальної нагородної, вогнепальної мисливської, холодної, пневматичної, газової) та пристроїв вітчизняного виробництва для відстрілу патронів, споряджених гумовими чи аналогічними за своїми властивостями метальними снарядами несмертельної дії, що перебувають у користуванні громадян, та необхідністю сурового дотримання дозвільної системи у цій сфері.

Метою нашої статті $\epsilon$ розгляд порядку здійснення контролю за дозвільною системою, під яку підпадають громадяни - власники зброї.

Конституція України визначає право кожного громадянина на захист свого життя та здоров'я, життя чи здоров'я інших осіб від протиправних посягань. Кримінальне законодавство визначає такі дії, як необхідну оборону. Необхідною обороною визнаються дії, вчинені з метою захисту охоронюваних законом прав та інтересів особи, яка захищається, або іншої особи, а також суспільних інтересів та інтересів держави від суспільно небезпечного посягання шляхом заподіяння тому, хто посягає, шкоди, необхідної і достатньої в такій обстановці для негайного відвернення чи припинення посягання, якщо при цьому не було допущено перевищення меж необхідної оборони.

Кожна особа має право на необхідну оборону незалежно від можливості уникнути суспільно небезпечного посягання або звернутися за допомогою до інших осіб чи органів влади. Перевищенням меж необхідної оборони визнається умисне заподіяння тому, хто посягає, тяжкої шкоди, яка явно не відповідає небезпечності посягання або обстановці захисту. Не $\epsilon$ перевищенням меж необхідної оборони і не має наслідком кримінальну відповідальність застосування зброї або будь-яких інших засобів чи предметів для захисту від нападу озброєної особи або нападу групи осіб, а також для відвернення протиправного насильницького вторгнення у житло чи 
інше приміщення, незалежно від тяжкості шкоди, яку заподіяно тому, хто посягає.

Громадяни України для здійснення необхідної оборони мають право на придбання вогнепальної зброї, пневматичної зброї калібру понад 4,5 мм та швидкістю польоту кулі понад 100 метрів за секунду (далі - пневматична зброя) і холодної зброї (арбалети, луки із зусиллям натягу тятиви більше ніж 20 кг, мисливські ножі тощо (далі - холодна зброя)), газових пістолетів і револьверів та патронів до них, заряджених речовинами сльозоточивої та дратівної дії (далі - газова зброя), пристроїв вітчизняного виробництва для відстрілу патронів, споряджених гумовими чи аналогічними за своїми властивостями метальними снарядами несмертельної дії (далі - пристрої), та патронів до них, основних частин зброї, бойових припасів до зброї. При цьому громадяни зобов'язані суворо дотримуватися правил дозвільної системи.

Національна поліція України (поліція) - це центральний орган виконавчої влади, який служить суспільству шляхом забезпечення охорони прав і свобод людини, протидії злочинності, підтримання публічної безпеки і порядку.

Основними завданнями органів поліції у сфері дозвільної системи $€$ запобігання порушенням порядку виготовлення, придбання, зберігання, обліку, охорони, перевезення та використання. Поліція у сфері дозвільної системи здійснює контроль за дотриманням фізичними та юридичними особами спеціальних правил та порядку зберігання і використання зброї, спеціальних засобів індивідуального захисту та активної оборони, боєприпасів, вибухових речовин і матеріалів, інших предметів, матеріалів та речовин, на які поширюється дозвільна система органів внутрішніх справ, здійснює у визначеному законом порядку приймання, зберігання та знищення вилученої, добровільно зданої або знайденої вогнепальної, газової, холодної та іншої зброї, боєприпасів, набоїв, вибухових речовин та пристроїв, наркотичних засобів або психотропних речовин.

Для виконання поліцейських повноважень (функцій) поліція має право на застосування поліцейських заходів. Поліцейський захід - це дія або комплекс дій превентивного або примусового характеру, що обмежує певні права і свободи людини та застосовується поліцейськими відповідно до закону для забезпечення виконання покладених на поліцію повноважень. Поліцейський захід застосовується виключно для виконання повноважень поліції. Обраний поліцейський захід має бути законним, необхідним, пропорційним та ефективним.

У статті ми розглянемо порядок проведення одного із видів превентивних поліцейських заходів - перевірку дотримання вимог дозвільної системи органів внутрішніх справ, а саме ії дотримання громадянами (фізичними особами).

Станом на 31 грудня 2018 року в Україні перебуває на обліку у Національній поліції 753902 одиниці гладкоствольної зброї, 151862 нарізної та 71320 газової зброї. Крім того, зареєстровано 210166 пристроїв. За 2018 рік 74 рази застосовувалася зареєстрована зброя та пристрої. При цьому було вбито 31 особу та 40 осіб було поранено.

Ми умисно не розглядаємо порядок контролю за об'єктами дозвільної системи (сховищ, складів, де зберігаються вибухові матеріали і речовини, стрілець- ких тирів і стрільбищ, мисливсько-спортивних стендів, а також підприємств і майстерень з виготовлення і ремонту вогнепальної, холодної та охолощеної зброї, спеціальних засобів, заряджених речовинами сльозоточивої та дратівної дії, індивідуального захисту, активної оборони, магазинів, у яких здійснюється продаж зброї та бойових припасів до неї, основних частин зброї, пристроїв та патронів до них). Такий контроль здійснюють поліцейські підрозділи превентивної діяльності, які згідно зі своїми функціональними обов'язками відповідальні за дозвільну систему. Зазначені поліцейські $\epsilon$ більш компетентними у викладеному питанні. Інші поліцейські, що в ході повсякденної службової діяльності можуть стикатися з власниками зброї, також мають досконало знати правила дозвільної системи, порядок зберігання, носіння, перевезення зброї та боєприпасів, а також можливі правопорушення у цій сфері. Це можуть бути патрульні поліцейські, співробітники кримінальної поліції, поліції особливого призначення, слідчі та поліцейські чергової служби поліції тощо.

Дозвільна система, що здійснюється органами поліції, поширюється на бойову нарізну військових зразків зброю або виготовлену за спеціальним замовленням, охолощену, нейтралізовану, несучасну, спортивну, мисливську вогнепальну зброю, бойові припаси до зброї, основні частини зброї, пневматичну, газову, холодну зброю, пристрої та патрони до них, що належать підприємствам, установам, організаціям, суб'єктам господарювання та громадянам.

Вогнепальна зброя - зброя, яка призначена для ураження цілей снарядами, що одержують спрямований рух у стволі (за допомогою сили тиску газів, які утворюються в результаті згоряння метального заряду) та мають достатню кінетичну енергію для ураження цілі, що знаходиться на визначеній відстані.

Бойова вогнепальна зброя - вогнепальна зброя, призначена для ураження людини та (або) техніки. До бойової зброї не належить старовинна зброя та ії моделі, які виготовлені до 1899 року включно.

До несучасної зброї належить вогнепальна і холодна зброя, яка: знята з озброєння армії та виробництва і для якої серійно не випускаються боєприпаси; знята з озброєння зброя і яка існує в одиничних екземплярах; виготовлена спеціально для виставок (експонування) в одиничних екземплярах.

Охолощена зброя - пристрої, виготовлені шляхом спеціального пристосування конструкції стрілецької вогнепальної зброї до стрільби лише холостими патронами, з яких неможливо зробити постріл снарядом, що має достатню вражаючу здатність. Призначена для використання на кінозйомках, для проведення театралізованих, костюмованих та інших культурних заходів. Охолощена зброя на заводах-виготовлювачах чи в майстернях з ремонту зброї має бути приведена у стан, придатний для стрільби тільки холостими патронами, що підтверджується відповідним висновком.

Нейтралізована зброя - стрілецька зброя будь-якої моделі, яка з дотриманням вимог відповідних стандартів або технічних умов спеціально приведена на заводах-виробниках чи у спеціалізованих майстернях з ремонту зброї в непридатний для стрільби стан. Кожна одиниця нейтралізованої зброї мусить мати відповідний висновок про незворотне приведення іï в непридатний для проведення пострілів стан та віднесення ії до пев- 
ного виду нейтралізованої зброї. На кожну одиницю нейтралізованої зброї наносять серійний номер та абревіатуру виду нейтралізованої зброї.

Нейтралізована зброя залежно від іï призначення класифікується як:

- учбова зброя - зброя, яка спеціально приведена в непридатний для стрільби стан, призначена для навчання правил поводження зі зброєю (розбирання та складання, заряджання та розряджання, виконання стройових прийомів зі зброєю) (абревіатура виду - Уч);

- учбово-розрізна зброя - зброя, яка спеціально приведена в непридатний для стрільби стан, основні деталі якої мають спеціально виконані вирізи, призначені для забезпечення наочності під час вивчення порядку взаємодії деталей і вузлів (абревіатура виду - УЧР);

- музейна зброя - зброя, яка спеціально приведена в непридатний для стрільби стан та призначена виключно для експонування в музеях (абревіатура виду - МУЗ);

- макети зброї масогабаритні - конструктивно подібні до вогнепальної зброї вироби, призначені для колекціонування та експонування фізичними і юридичними особами, які спеціально виготовлені з вогнепальної стрілецької зброї шляхом внесення до конструкції ії основних частин та механізмів змін, що виключають здійснення пострілу (абревіатура виду - ММГ).

Спортивна зброя - вогнепальна, пневматична або холодна зброя, призначена для ураження цілей під час спортивних тренувань і змагань, що відповідає правилам спортивних змагань з видів спорту, визнаних в Україні, що затверджуються центральним органом виконавчої влади, який забезпечує формування державної політики у сфері фізичної культури та спорту, з урахуванням пропозицій відповідних всеукраїнських спортивних федерацій та правил спортивних змагань відповідної міжнародної спортивної федерації.

Мисливська вогнепальна зброя - вогнепальна зброя, призначена для ураження тварин і птахів під час полювання. До мисливської вогнепальної зброї належать: мисливські гвинтівки, карабіни та штуцери, гладкоствольні рушниці, гладкоствольні рушниці зі свердловиною «парадокс» з нарізами 100-140 мм на початку або наприкінці ствола, мисливські рушниці зі свердловиною “сюпра», комбіновані рушниці, що мають поряд з гладкими і нарізні стволи.

Мисливська зброя має відповідати таким вимогам: для стрільби зі зброї використовуються мисливські патрони відповідного калібру; загальна довжина з розкладеним та зафіксованим прикладом має становити не менше 800 мм; ємність магазину (барабана) (з установленим обмежувачем за наявності) нарізної зброї не має перевищувати 10 патронів, а гладкоствольної - 4 патронів; мати запобіжник.

Газова зброя - газові пістолети і револьвери та патрони до них калібру 6, 8 і 9 міліметрів, заряджені речовинами сльозоточивої та дратівної дії.

Для зарядження вказаних спеціальних засобів самооборони допускаються рецептури на основі речовин сльозоточивої та дратівної дії, які пройшли токсично-гігієнічні випробування і допущені до використання Кабінетом Міністрів України.

Боєприпаси - спеціально виготовлені вироби одноразового використання, які призначені забезпечити ураження цілей в умовах збройної боротьби, самооборони, полювання, спорту. До бойових припасів належать патрони до нарізної вогнепальної зброї різних калібрів, а також заряджені патрони до гладкоствольних мисливських рушниць, мисливський порох і капсулі.

До пневматичної зброї належать пістолети, револьвери, гвинтівки калібру понад 4,5 міліметра і швидкістю польоту кулі понад 100 метрів за секунду, в яких снаряд (куля) приводиться в рух за рахунок стиснених газів.

Холодна зброя - предмети та пристрої, конструктивно призначені та за своїми властивостями придатні для неодноразового заподіяння шляхом безпосередньої дії тяжких (небезпечних для життя в момент спричинення) і смертельних тілесних ушкоджень, дія яких ґрунтується на використанні м'язової сили людини.

До пристроїв належать такі пістолети і револьвери вітчизняного виробництва, які конструктивно призначені тільки для відстрілу патронів, споряджених гумовими чи аналогічними за своїми властивостями метальними снарядами несмертельної дії і технічно не придатні для стрільби бойовими патронами. При цьому їхня конструкція має забезпечувати неможливість взаємозаміни основних частин бойової і спортивної вогнепальної зброї, унеможливлює здійснення пострілів в автоматичному режимі чергами. Патрони до пристроїв - патрони, споряджені гумовими чи аналогічними за своїми властивостями метальними снарядами несмертельної дії, призначені для відстрілу їх тільки пристроями вітчизняного виробництва i допущені в установленому порядку до використання.

До основних частин зброї належать будь-які елементи або запасні деталі, спеціально призначені для вогнепальної зброї та необхідні для їі функціонування, а саме: ствол, корпус або стовбурна коробка, затвор або барабан, вісь затвору або казенник.

Поліція може оглядати зброю, спеціальні засоби, боєприпаси, що знаходяться у фізичних осіб, інші предмети, матеріали і речовини, щодо зберігання та використання яких визначено спеціальні правила чи порядок та на які поширюється дозвільна система органів внутрішніх справ, з метою перевірки дотримання правил поводження з ними та правил їх використання. Проведення перевірки правил дозвільної системи (огляд зброї та боєприпасів) поліцейськими може бути проведено:

1. Під час проведення поверхневої перевірки особи чи транспортного засобу для здійснення контролю у разі допуску громадян на територію або об'єкт зі спеціальним режимом.

2. Під час поверхневої перевірки особи чи транспортного засобу на місці скоєння кримінального чи адміністративного правопорушення.

3. Під час прийому черговою службою добровільно зданої зброї.

4. Під час проведення обшуку.

5. Під час здійснення заходів щодо попередження порушень правил полювання.

6. Під час патрулювання.

7. Під час несення служби на блокпостах у зоні проведення Операції об'єднаних сил.

Окремо необхідно відзначити деякі особливості огляду зареєстрованої вогнепальної зброї.

Кожна одиниця зброї мусить мати відповідне маркування, нанесене безпосередньо на зброю. Якість маркування має бути достатньою для зручного прочитання всієї інформації. 
Маркування нарізної та гладкоствольної зброї має містити: ника;

знак для товарів та послуг підприємства-вироб-

назву моделі зброї;

- заводський номер зброї;

калібр патрона, що використовується (на кожному стволі);

- національний знак відповідності за наявності сертифіката відповідності (для зброї, виробленої в Україні);

- напис «Вироблено в Україні» (для зброї, виробленої в Україні); клейма.

рік випробування, за наявності випробувального

Маркування на гладкоствольній зброї додатково має містити довжину патронника. Заводський номер на зброю, виготовлену зі зброї військового призначення або з використанням її основних частин, або розроблену на іï базі (якщо при цьому залишається можливість використання іï основних частин для заміни аналогічних частин бойової зброї), наносять виключно ударним способом або методом холодного тиснення глибиною не менше ніж 0,2 мм. Заводський номер наносять на такі основні частини зброї: ствольну коробку або рамку. Додатково заводський номер наносять на ствол, затвор, затворну раму, барабан, кожух затвору та інші частини, якщо це передбачено виробником.

Для зброї, виготовленої зі зброї військового призначення та багатоцільової зброї у мисливському або спортивному виконанні, заводський номер додатково має бути нанесено на ствол, затвор, затворну раму, барабан, кожух затвору та магазин (чотири останні цифри номера).

Загальні технічні вимоги.

Мисливська зброя має відповідати таким вимогам: для стрільби зі зброї використовуватимуть мисливські патрони відповідного калібру; мати загальну довжину з розкладеним та зафіксованим прикладом не менше 800 мм; ємність магазину (барабану) нарізної зброї не перевищує 10 патронів, а гладкоствольної (зі встановленим обмежувачем - за його наявності) - 4 патронів; мати запобіжник; довжина ствола нарізної зброї більше 200 мм, гладкоствольної - не менше 450 мм.

Зброя має забезпечувати: безвідмовне функціонування затвору та замикального механізму; безвідмовну роботу замикального та викидального механізмів самозарядної зброї; безвідмовне вмикання запобіжника; безвідмовну роботу механізму барабана револьвера; неможливість пострілу від інерційного наколу (для самозарядної зброї); неможливість випадкового пострілу через зрив курків із шептал під час перезарядження, зачинення каналу ствола, зведення шнелера та постановки на запобіжник; неможливість заклинювання деталей ударно-спускового механізму та затвора, коли запобіжник включений; неможливість проведення більше одного пострілу у разі одноразового натискання на спусковий гачок; неможливість стрільби зі складеним або неповністю зафіксованим у розкладеному вигляді прикладом (у т.ч. і з використанням допоміжних пристосувань) без внесення незворотних змін у конструкцію зброї.

Для довгоствольної нарізної мисливської та спортивної зброї допускається можливість стрільби зі складеним або неповністю зафіксованим у розкладеному вигляді прикладом, якщо при цьому загальна довжина такої зброї зі складеним прикладом та зі знятими від'ємними дульними насадками (подовжувачі, дульні гальма, полум'ягасники, зменшувачі звуку пострілу) перевищує 800 мм. Конструкція зброї має забезпечувати неможливість пострілу з вільним падінням зброї на дерев'яну поверхню з висоти, значення якої наведено в нормативній документації на зброю. Розміри патронників та каналів стволів нарізної та гладкоствольної зброї під патрон відповідного калібру мають знаходитись у межах допусків, указаних у нормативній документації на зброю. Конструкція зброї, яка виготовлена шляхом перероблення зі зброї військового призначення, додатково має забезпечувати:

відсутність можливості заміни ствола, ствольної коробки та магазину мисливської (спортивної) зброї аналогічними деталями зброї військового призначення без внесення видимих неозброєним оком незворотних змін у їі конструкцію;

відсутність можливості використання ствола, ствольної коробки та магазину мисливської (спортивної) зброї для комплектування бойової зброї без внесення видимих неозброєним оком незворотних змін у конструкцію цих частин;

- відсутність можливості автоматичної стрільби;

відсутність можливості відновлення автоматичної стрільби за допомогою універсального інструменту загального вжитку (молоток, плоскогубці, викрутки та виколотки, пінцет, ручний дриль тощо);

- відсутність кріплення для штик-ножа (штика);

- обмеження дальності стрільби на відкритих прицільних механізмах до 300 м.

Конструкція магазину мусить мати невід'ємний обмежувач кількості патронів, а саме: для нарізної зброї (окрім спортивної) - до 10 патронів; для гладкоствольної зброї - до 4 патронів. Зброя, яка виготовлена шляхом перероблення зі зброї військового призначення, має залишати на стріляних із неї кулях та гільзах сліди, придатні для визначення ï моделі та виробника (криміналістичні мітки). Сліди, котрі залишаються на кулях та гільзах під час пострілу з мисливської (спортивної) зброї, мають відрізнятися від слідів аналогічної зброї військового призначення, з якої вони виготовлені.

Поліція відповідно до порядку, визначеного Міністерством внутрішніх справ України, вилучає зброю, спеціальні засоби, боєприпаси, вибухові речовини та матеріали, інші предмети, матеріали і речовини, щодо зберігання і використання яких визначено спеціальні правила чи порядок та на які поширюється дозвільна система органів внутрішніх справ, у разі виявлення порушення правил поводження з ними та правил їх використання, що загрожують громадській безпеці, до усунення таких порушень.

\section{Література}

1. Конституція України від 28.06.1996 року. URL: http://zakon2.rada.gov.ua/.

2. Кримінальний кодекс України від 05.04.2001 року. URL: http://zakon.rada.gov.ua/laws/show/2341-14.

3. Кримінальний процесуальний кодекс України від 13.04.2012 року. URL: http://zakon.rada.gov.ua/laws/ show/4651-17.

4. Закон України «Про Національну поліцію» від 05.07.2015 року. URL: zakon.rada.gov.ua/laws/show/580-19. 
5. Закон України «Про запобігання та протидію домашньому насильству» від 07.12.2017 року. URL: http: // zakon.rada.gov.ua/laws/show/2229-19.

6. Постанова Верховної Ради України «Про право власності на окремі види майна". Відомості Верховноі Ради України (ВВР), 1992, № 35, ст. 517 зі змінами.

7. Постанова Кабінету Міністрів України № 576 від 12.10.1992 року «Про затвердження Положення про дозвільну систему». URL: https://zakon.rada.gov.ua/laws/ show $/ 576-92-\% D 0 \% B F$.

8. Постанова Кабінету Міністрів України № 706 від 07.09.1993 року «Про порядок продажу, придбання, реєстрації, обліку і застосування спеціальних засобів самооборони, заряджених речовинами сльозоточивої та дратівної діï». URL: https://zakon.rada.gov.ua/laws/show/706-93$\% \mathrm{DO} \% \mathrm{BF}$

9. Наказ Міністерства внутрішніх справ України № 611 від 21.08.1998 року «Про затвердження Інструкції про порядок виготовлення, придбання, зберігання, обліку, перевезення та використання вогнепальної, пневматичної, холодної і охолощеної зброї, пристроїв вітчизняного виробництва для відстрілу патронів, споряджених гумови- ми чи аналогічними за своїми властивостями метальними снарядами несмертельної дії, та патронів до них, а також боєприпасів до зброї, основних частин зброї та вибухових матеріалів». URL: https://zakon.rada.gov.ua/laws/show/ z0637-98.

10. Наказ Міністерства внутрішніх справ України № 611 від 21.08.1998 року «Про затвердження Змін та доповнень до стандарту МВС України ГСТУ 78-41-002-97». URL: http://mvs.gov.ua/upload/file/nakaz3.pdf.

Ташматов В. A., кандидат психологічних наук, підполковник поліції, доцент кафедри тактико-спеціальної, вогневої та фізичної підготовки

Одеського державного університету внутрішніх справ

Прядко В. М., підполковник поліції, старший викладач кафедри тактико-спеціальної, вогневої та фізичної підготовки одеського державного університету внутрішніх справ 